HTTP://DX.DOI.ORG/10.12775/SZHF.2016.046

\title{
Estetyka Mosesa Mendelssohna jako filozofia psychologii
}

W ramach prezentacji historii estetyki niemieckiego Oświecenia jeszcze do niedawna zapominano o postaci, która stanowiła łącznik pomiędzy metafizycznie zorientowaną estetyką Wolffa i Baumgartena a teorią literatury i sztuki Lessinga i Winckelmanna. Postacią tą był Moses Mendelssohn (1729-1786). W historii estetyki przedstawiany jest on najczęściej jako ktoś, kto porzuca estetykę opartą na pojęciu doskonałości i zwraca się ku badaniom subiektywnego doświadczenia piękna i sztuki, co przybliża go z jednej strony do myślicieli takich jak Hutcheson czy Burke, z drugiej zaś, do takich jak Du Bos i Rousseau. Niekiedy przedstawia się go również jako myśliciela antycypującego Kantowską doktrynę trzech władz ${ }^{1}$.

Wydaje się, że wspomniane interpretacje są nieuzasadnione. Z pewnością nie można widzieć w Mendelssohnie tego, który poddał się irracjonalizmowi epoki Sturm und Drang. Wręcz przeciwnie, stawiał on sobie wyraźnie za cel obronę racjonalizmu przed prądami podważającymi rolę rozumu. Z jednej strony zmagał się z myślicielami angielskimi odwołującymi się do posiadania przez człowieka specjalnego rodzaju zmysłu piękna, z drugiej polemizo-

${ }^{1}$ Por. K. Hammermeister, The German Aesthetic Tradition, Cambridge University Press, Cambridge 2002, s. 18-19. 
wał z kultem geniusza, który epoka zaczerpnęła głównie z pism Rousseau. Nie wydaje się również zasadne, aby rozważać myśl Mendelssohna wyłącznie w kontekście filozofii Kanta. Nie oddawałoby to sprawiedliwości ani myśli Kanta, ani oryginalności myśli Mendelssohna. Estetykę tego ostatniego należy zatem rozpatrywać na jej własnych prawach.

Konieczna jest również uwaga dotycząca kwestii spójności pism Mendelssohna. Niemiecki filozof o estetyce pisał wiele i przez całe życie. Nie można jednak wskazać głównego dzieła, które prezentowałoby całość jego poglądów estetycznych. Może to rodzić często spotykany w stosunku doń zarzut, że jego estetyczna myśl była eklektyczna i podlegała nieustannym zmianom². W niniejszym artykule twierdzę jednak, że zarzut niespójności wynika stąd, że przyjmujemy złą perspektywę badawczą, to znaczy, że szukamy nie w tym miejscu, w którym szukać powinniśmy. Jak spróbuję wykazać, jeżeliby interpretować badania estetyczne jako analizę problematyki z zakresu antropologii i filozofii umysłu ${ }^{3}$, to wydaje się, że możliwe jest wskazanie wątków, które konsekwentnie pojawiają się w całej twórczości filozoficznej Mendelssohna (co nie oznacza, że nie podlegają udoskonaleniu i modyfikacji).

Ostatnia uwaga dotyczy zarzutu o „popularność” filozofii Mendelssohna. Przyjęło się w historii filozofii zaliczać autora Listów o odczuciach do grupy tzw. filozofów popularnych, których rola polegała przede wszystkim na popularyzacji myśli Wolffa. Bez wątpienia Mendelssohn był pod głębokim wpływem Wolffiańskiego racjonalizmui z pewnością jego intencją była obrona filozoficznych osiągnięć niemieckiego Oświecenia. Nie oznacza to jednak, że przez oświeceniową „filozofię popularną” możemy rozumieć filozofię obliczoną jedynie na dotarcie do masowego odbiorcy, czyli filozofię spłyconą i nieoryginalną. Mendelssohn był wprawdzie autorem współcześnie szeroko czytanym i komentowanym, ale w takim rozumieniu popularnym autorem był również Kant. Nieuprawniony jest także zarzut o nieoryginalność. Jak spróbuję wykazać, myśl Mendelssohna czerpie z dokonań poprzedników, ale rozważaniom estetycznym wyznacza również nowy kierunek, zwracając uwagę na emocjonalne komponenty naszego poznania.

2 Por. A. Pollok, Einleitung, [w:] Moses Mendelssohn, Ästhetische Schriften, hrsg. A. Pollok, Felix Meiner Verlag, Hamburg 2006.

${ }^{3}$ Podobną strategię interpretacyjną starałem się przedstawić w P. Kozak, Wychować Boga. Estetyka antropologiczna Alexandra Gottlieba Baumgartena na tle myśli niemieckiej pierwszej połowy XVIII wieku, Wyd. UW, Warszawa 2013. 


\section{Analiza roli odczuć zmysłowych}

Problematyka estetyczna pojawia się u Mendelssohna wcześnie, to jest $\mathrm{w}$ połowie lat 50. XVIII wieku w Briefe über die Empfindungen oraz w Rhapsodie, oder Zusätze zu den Briefen über die Empfindungen. Oba dzieła, jak wskazują tytuły, poświęcone były odczuciom. Byłoby jednak błędem twierdzić, że oba dotyczą wyłącznie zagadnień estetycznych, rozumianych jako analiza doświadczenia piękna i sztuki. Pytanie, jakie stawia Mendelssohn (podkreśla to szczególnie mocno w swojej interpretacji Beiser ${ }^{4}$ ), jest głębsze i dotyczy zagadnienia: co czyni życie życiem dobrym. Jest to powód, dla którego Listy o odczuciach niemal w jednej trzeciej poświęcone są analizie problemu samobójstwa. Zjawisko samobójstwa podnosi bowiem problem, czy istnieją wartości wyższe ponad życie, które mogą ewentualnie stanowić dla życia rację. Dopiero w tym szerszym kontekście można zrozumieć Mendelssohnowskie analizy dotyczące odczucia przyjemności i nieprzyjemności.

Problem związany z dyskusją na temat odczuć autor Listów o odczuciach dostrzegał jednak przede wszystkim w bezrefleksyjnym odwoływaniu się do emocji oraz odżegnywaniu się od roli rozumu w etyce i estetyce, co czynili chociażby Holbach czy Du Bos. Ci ostatni utrzymywali: po pierwsze, że przyjemność jest prosta i nie podlega analizie pojęciowej, po drugie, że odczucie przyjemności daje się sprowadzić do postaci sensualnej, na przykład do określonego stanu pobudzenia nerwów, po trzecie, że dobre życie polega na doświadczaniu przyjemności zmysłowej. Tym samym dla empirystów francuskich moralność i estetyka miały charakter niekognitywny i niedyskursywny.

Intencją Mendelssohna było $\mathrm{z}$ kolei zrozumienie funkcji, jaką pełnią odczucia, w szczególności odczucie przyjemności płynące $\mathrm{z}$ doświadczenia piękna, w kontekście rozważań na temat natury ludzkiej i dobrego życia. $\mathrm{W}$ tym sensie badał on również relację pomiędzy rozumem a zmysłami, czyli zgłębiał problem, na ile są to władze oddzielne i w jakim sensie możemy mówić o ich współpracy. Badał zatem, czym są odczucia, jak działają i jak ma się do nich myślenie. Co ważne, mimo że Mendelssohn uważany jest często za tego, który przeniósł angielską myśl estetyczną na grunt niemiecki, to autor Listów o odczuciach nigdy nie zaakceptował rozwiązań odwołujących się do specjalnego rodzaju zmysłu piękna, którego istnienie postulowali filozofowie

${ }^{4}$ F. Beiser, Diotima's Children: German Aesthetic Rationalism from Leibniz to Lessing, Oxford University Press, New York 2009, s. 199. 
tacy jak Hutcheson. Ten ostatni twierdził, że człowiek został celowo obdarzony zmysłem estetycznym, aby w doświadczeniu estetycznym móc dostrzegać wolę i dzieło Boga-stwórcy ${ }^{5}$. Mendelssohn uważał takie rozwiązanie za arbitralne i oparte na wątpliwych przesłankach:

Nie odwołujmy się do bezpośredniej woli Boga. Nie twórzmy, tak jak czynią to angielscy filozofowie, nowego zmysłu piękna, który najwyższa istota, posiadając dobre intencje, rzekomo umieściła stosownie do stopnia w naszych duszach. Jest to najprostsza droga do tego, by przerwać racjonalne rozważania i przekształcić naturę, najdoskonalszą całość, w zbieraninę przypadkowych elementów ${ }^{6}$.

W tym miejscu Mendelssohn niewątpliwie zgadza się ze Spinozą odrzucającym wolę Boga jako wytłumaczenia wszystkiego, co zachodzi we wszechświecie, które to wytłumaczenie sam autor Etyki nazywał „ostoją ignorancji”. $\mathrm{Z}$ drugiej strony Mendelssohn podejmuje problem przyczyny celowej od strony rozważań Leibniza. Ten ostatni przyznawał, że Bóg wprawdzie stworzył świat stosownie do swojej woli (przyczyny celowej), ale dokonał tego poprzez przyczyny sprawcze. O ile zatem nie jesteśmy w stanie poznać przyczyny celowej ani woli Boga, o tyle jesteśmy w stanie odkryć przyczyny sprawcze. Dzięki temu możemy poszerzyć naszą wiedzę o wszechświecie oraz opisać przyczynową strukturę wszechświata. Mendelssohn pisze:

Musimy odróżnić święte intencje od przyczyn sprawczych. Najdoskonalszy $\mathrm{z}$ rzemieślników wie, $\mathrm{w}$ jaki sposób spełnić najmądrzejsze $\mathrm{z}$ intencji poprzez zastosowanie najmądrzejszych środków. Jego mądrość dokonała wyboru najdoskonalszych celów, ale to poprzez najmądrzejsze pogodzenie przyczyn sprawczych te cele zrealizował. Tym samym, jeżeli łaskawy stwórca uznał, że ludzie powinni czerpać satysfakcję z obcowania z pięknem, to sprawił również, że ich umysły posiadają taką budowę, która sprawia, że owa satysfakcja wypły-

${ }^{5}$ F. Hutcheson, An Inquiry into the Original of Our ideas of Beauty and Virtue (1725), (ed.) K. Haakonssen. Liberty Fund, Indianapolis 2002.

${ }^{6}$ M. Mendelssohn, Betrachtungen über die Quellen und die Verbindungen der schönen Künste und Wissenschaften, [w:] tenże, Gesammelte Schriften Jubiläumsausgabe, hrsg. A. Altmann, F. Bamberger, H. Borodianski, I. Elbogen, J. Guttmann, E. Mittwoch, S. Rawidowicz, B. Strauss, L. Strauss, Friedrich Frommann, Berlin-Stuttgart 1929-1976, t. 1, s. 169. Dalej jako JubA.

${ }^{7}$ B. Spinoza, Etyka w porządku geometrycznym dowiedziona, przeł. I. Halpern-Myslicki, [w:] tenże, Traktaty, Wyd. Antyk, Kęty 2003, s. 494. 
wa naturalną drogą z owych umysłów oraz może być wytłumaczona poprzez odwołanie się do budowy umysłu8.

Dystansuje się on zatem od rozważań angielskich empirystów, którzy przeczyli możliwości racjonalnego wyjaśnienia sądu estetycznego. Niemiecki filozof nie szuka mitycznego zmysłu estetycznego, który w nieuchwytny sposób odpowiedzialny byłby za rozpoznawanie piękna. Mendelssohn chce zrozumieć i wyjaśnić, w jaki sposób rozpoznajemy piękno, w jaki sposób uzasadniamy nasze sądy estetyczne oraz co wyróżnia sąd estetyczny ze zbioru wszystkich sądów. Wszystko to stara się czynić w odwołaniu jedynie do przyczyn naturalnych.

Nie ulega oczywiście wątpliwości, że Mendelssohn studiował myśl angielską oraz francuską, w szczególności myśl Du Bos’a oraz Batteux. Bezpośrednią inspiracją były jednak rozważania, z jednej strony, Leibniza i Wolffa, z drugiej Baumgartena, z trzeciej - Spinozy. Od tego ostatniego zaczerpnął w szczególności idee dotyczące sprawczej roli afektów.

Badania dotyczące ludzkich emocji rozpoczyna on od pytania o doświadczenie przyjemności, ściślej, chce znaleźć wyjaśnienie oraz stosowny opis dla różnych stopni oraz rodzajów doświadczenia przyjemności i nieprzyjemności. Celem tak postawionego pytania ma być wyjaśnienie roli, jaką odgrywają odczucia oraz afekty w ludzkim działaniu i poznaniu. Przyjmuje przy tym przesłankę, że istnieje możliwość zredukowania uczucia piękna i wzniosłości, tak w sztuce, jaki w życiu codziennym, do natury ludzkiego umysłu oraz jego zdolności do doświadczania i rozpoznawania emocji. Filozof rozumie zatem badania estetyczne jako badania sposobu, w jaki funkcjonuje nasz umysł. W Głównych zasadach sztuk i nauk pięknych, pisze:

Każda z reguł piękna jest zarazem regułą psychologiczną. Jeżeli zawiera ona zalecenia odnośnie do warunków, zgodnie z którymi piękny przedmiot może mieć najlepszy wpływ na nasz umysł, to musi być możliwe, aby ta reguła mogła być wyprowadzona z natury ludzkiego umysłu i wyjaśniona na bazie własności umysłu?.

Co ważne, pytanie Mendelssohna o charakter ludzkich emocji różni się od analogicznego pytania stawianego przez Baumgartena i Meiera (ale również Kartezjusza). Ci ostatni rozważali uczucie przyjemności i nieprzyjemności

\footnotetext{
${ }^{8}$ M. Mendelssohn, Betrachtungen über die Quellen..., [w:] JubA 1, s. 169.

9 Tenże, Ueber die Hauptgrundsätze der schönen Künste und Wissenschaften, [w:] JubA 1, s. 427.
} 
- czym zasadniczo nie odbiegali od poglądów typowych dla nowożytności - w kontekście doświadczenia doskonałości i niedoskonałości przedmiotu, gdzie doskonałość była definiowana jako pewna wielość podporządkowana jednemu celowi, to jest posiadająca jedność. W myśl założeń filozofii umysłu Kartezjusza, Wolffa i Baumgartena owa forma wewnętrznego porządku poruszała władzę wyobraźni, powodując powstanie uczucia przyjemności. Mendelssohn analizuje z kolei uczucie przyjemności i nieprzyjemności w oderwaniu od jakiegokolwiek poznania doskonałości przedmiotu. W tekście Von dem Vergnügen ${ }^{10}$ niemiecki filozof zauważa, że możemy wyodrębnić szereg przypadków, w których odczuwamy przyjemność z zaspokojenia cielesnego pożądania, jednak nie jest to ani powodowane, ani nie ma na celu doświadczenia doskonałości. $Z$ drugiej strony Mendelssohn podejmuje myśl obecną w szkole Wolffa, kiedy doświadczenie przyjemności przypisuje nabywaniu wiedzy, poznaniu prawdy, spełnianiu obowiązków, jak i rozwiązywaniu problemów matematycznych ${ }^{11}$. Przyjemność nie ma zatem charakteru prostego, jak chcieli tego sensualiści.

Pojawia się oczywiście pytanie: w jaki sposób wszystkie wspomniane rodzaje przyjemności mogą być wyjaśnione $\mathrm{w}$ ramach jednego paradygmatu badawczego? Rozwiązanie Mendelssohna jest w pierwszej kolejności negatywne: twierdzi on, że nie daje się odpowiedzieć na to pytanie, jedynie poprzez odwołanie do mętnych przedstawień (jak u Meiera) lub racjonalnego poznania (jak u Wolffa). Nic nie daje również odwołanie się do niższej władzy poznania, jak u Baumgartena. Mendelssohn próbuje znaleźć wspólną przyczynę różnych rodzajów przyjemności, przy czym owa przyczyna musiałaby z konieczności być wspólna dla ciała i umysłu. Ową wspólną przyczynę odnajduje w przejściu od niższego do wyższego stopnia doskonałości. Odczuwamy zatem przyjemność cielesną w wyniku odczucia przez umysł zgodności pomiędzy pobudzeniami cielesnymi ${ }^{12}$ a przyjemnością umysłową (w efekcie odczuwania zgodności pomiędzy ideami duchowymi ${ }^{13}$ ). Nietrudno zauważyć, że wspomniane rozwiązanie ma genezą Spinozjańską. Spinoza definiował uczucie przyjemności właśnie jako afekt wyrażający przejście od

10 Tenże, Von dem Vergnügen, [w:] JubA 1, 7.

${ }^{11}$ Por. tenże, Über die Empfindungen, [w:] JubA 1, s. 91.

${ }^{12}$ Przy czym Mendelssohn odróżnia explicite w Dodatku do Listów o odczuciach ciało (Körper) oraz ciało żywe (Leib). O ile w obu znaczeniach ciało podlega mechanicznym zmianom, o tyle jedynie ciało żywe, jako połączone ze świadomością funkcjonowania ciała, może być przedmiotem namysłu oraz podstawą posiadania świadomego odczucia rozkoszy cielesnej.

${ }^{13}$ Por. tenże, Über die Empfindungen, [w:] JubA 1, s. 83. 
niższego do wyższego stopnia doskonałości, bez względu na to, czy mówimy o przyjemności cielesnej czy duchowej.

Intencja, aby uwzględnić w obrębie rozważań na temat przyjemności doświadczenia cielesne, z pewnością wyróżnia Mendelssohna spośród jego poprzedników, tj. Baumgartena, Meiera, czy nawet Leibniza, dla których doświadczenie przyjemności miało przede wszystkim charakter poznawczy. Mendelssohn dostrzega, że przyjemność cielesna może być niezależna i genetycznie pierwotna w stosunku do poznania. Ulubionym przykładem filozofa jest przyjemność płynąca z miłości i picia wina. We wspomnianych przypadkach odczuwamy przyjemność będącą przejściem od mniejszej do większej doskonałości cielesnej bez względu na to, czy spostrzegamy tę doskonałość, czy nie. Tą doskonałością może być żywość ciała, jego większa sprawność, pobudzenie członków itp. Co istotne, na poziomie cielesnej przyjemności żadnej roli nie odgrywa moralna doskonałość przyjemności.

W celu stworzenia ogólnej teorii afektów Mendelssohn dokonuje również podziału w obrębie rodzajów przyjemności. Dzieli on przyjemność na: (1) zmysłową przyjemność cielesną; (2) piękno pojęte jako zmysłowo ujętą jedność $\mathrm{w}$ wielości (tak w sensie jedności cech przedmiotu, jak i jedności w przedstawieniu przedmiotu); (3) umysłową przyjemność płynącą z poznawania wewnętrznych relacji pomiędzy rzeczami oraz satysfakcję z posiadania zdolności kognitywnych umożliwiających takie poznanie. Łączy on następnie, analogicznie do rozważań Baumgartena, zmysłowe pożądania cielesne $\mathrm{z}$ ideami ciemnymi, a poznanie umysłowe $\mathrm{z}$ ideami jasnymi i wyraźnymi. Inaczej jest w przypadku piękna, które ujmujemy zmysłowo w jednym akcie poznawczym za pomocą idei jasnych i mętnych ${ }^{14}$. Idee wyraźne i mętne mogą

${ }^{14}$ Zgodnie z tradycją metafizyczną XVIII wieku „idee” należy rozumieć szeroko jako odpowiednik dzisiejszych „reprezentacji umysłowych”, co obejmuje zarówno reprezentacje ogólne, czyli pojęcia, jak i dane percepcyjne. Idee mogą być jasne, jeżeli posiadamy zdolność odróżniania ich od innych, lub ciemne, jeżeli takiej zdolności nie posiadamy. W obrębie idei jasnych możemy następnie rozróżnić idee jasne wyraźne oraz idee mętne. Idee jasne wyraźne to takie idee, których części możemy rozróżnić w odpowiednich sądach analitycznych, np. pojęcie „kawaler” możemy sprowadzić do koniunkcji pojęć „nieżonaty” i „mężczyzna”. Z kolei idee jasne mętne, to takie idee, których części składowych nie jesteśmy w stanie rozróżnić, np. możemy rozróżniać ideę miłości od nienawiści, ale nie musimy posiadać umiejętności analitycznego rozłożenia pojęcia „miłości”. Analogicznie możemy odróżniać obrazy zmysłowe od siebie, tj. możemy być zdolni do odróżnienia obrazu $X$ od nie- $X$, ale nie musimy posiadać umiejętności rozróżniania części $X$-a. Konieczna jest również uwaga odnośnie do tłumaczenia. Pojęcie „idea clara et confusa” tłumaczy się w polskiej literaturze przedmiotu bądź jako „idea jasna i niewyraźna”, bądź jako „idea jasna i mętna”. Obie propozycje rodzą wątpliwości, niemniej 
wprawdzie przechodzić w siebie nawzajem. W ten sposób, przykładowo, idee mętne możemy przekształcić z pomocą wysiłku poznawczego w idee wyraźne. Niemniej, czyniąc to, narażamy się na utratę doświadczenia piękna. Analogicznie każde doświadczenie analizowane za pomocą narzędzi naukowych może zostać ujęte od strony doświadczenia piękna, ale traci ono wówczas na swej wyraźności. Innymi słowy, możemy skupiać się na detalach, gubiąc ogląd całości i na odwrót.

Łącząc doświadczenie piękna z ideami mętnymi, Mendelssohn wyraźnie podąża za Baumgartenem i Meierem. Z drugiej strony, explicite krytykuje Baumgartena za zbyt radykalne rozdzielenie porządku idei mętnych oraz porządku idei wyraźnych i zbytnie skupienie uwagi na tych pierwszych ${ }^{15}$. Dla Mendelssohna istotna była (był to wątek, który zaczerpnął bezpośrednio z filozofii Leibniza i Wolffa) ciągłość pomiędzy tymi ideami. Krytykował również Baumgartena, za przecenianie roli zmysłów, szczególnie w metafizyce. Autor Listów odczuciach chciał zrozumieć, jak funkcjonuje ludzki umysłi w tym kontekście ważne było, aby oddać sprawiedliwość tak zmysłom, jak i rozumowi.

\section{Teoria odczuć mieszanych}

W swojej teorii odczuć Mendelssohn porzuca Baumgartena i zwraca się (choć nigdzie, m.in. ze względu na cenzurę, nie czyni tego explicite) ku Spinozie, od którego czerpie teorię afektów, oraz ku Leibnizowi, od którego zapożycza teorię poznania. Szczególnie istotny jest wpływ Spinozy w Mendelssohnowskiej koncepcji odczuć mieszanych. Autor Etyki twierdził, że emocje rozkoszy i smutku stanowią wyraz przejścia ku większemu lub mniejszemu stopniowi doskonałości, które to przejście stanowi dążenie (conatus) do samozachowania. Wedle Spinozy nie można jednak doświadczać czystej przyjemności i smutku. Mogą być one doświadczone jedynie poprzez odczucia mieszane, będące kombinacją wielu afektów oraz ich interakcji z otoczeniem. Mendelssohn przejął od Spinozy teorię afektów i na jej podstawie rozwinął teorię sądu estetycznego.

należy pamiętać, że w baumgartenowskiej tradycji estetycznej „idea confusa” nie oznaczała braku własności wyraźności, ale wskazywała na pewną autonomiczną własność, która miała być cechą wyróżniającą poznania zmysłowego.

${ }^{15}$ Tenże, A. G. Baumgarten: Aestheticorum Pars altera, [w:] JubA 4, s. 263-275. 
Punktem wyjścia Mendelssohnowskiej teorii odczuć mieszanych było pytanie, co powoduje, że przyjemne odczucia są wywoływane nie tylko przez piękne obrazy, ale również przez rzeczy nieprzyjemne, takie jak, zgodnie z przykładami Mendelssohna, zatonięcie statku, zagrażające życiu sztuczki akrobatyczne czy antyczne tragedie? Wspomniane obrazy mają niewiele lub nie mają nic wspólnego $\mathrm{z}$ doskonałością, pomimo to są one odbierane jako przyjemne. W celu wyjaśnienia tej wątpliwości Mendelssohn opracowuje wraz z Lessingiem i Christophem Friedrichem Nicolaiem teorię odczuć mieszanych, która pozwala mu włączyć w obręb teorii przyjemności przedmioty estetyczne, które przejawiają się jako brzydkie. W Listach o odczuciach pisze on o możliwości transformacji odczuć negatywnych (na przykład odczucia smutku) w odczucia pozytywne (na przykład radość). Bazując na Spinozjańskiej teorii afektów, Mendelssohn twierdzi, że rozbudzenie namiętności powoduje pobudzenie aktywności wyobraźni. Z kolei podwyższenie aktywności wyobraźni stanowi przejście ku wyższemu stopniowi doskonałości rozumianej (zgodnie z Baumgartenowskim podziałem na jasność intensywną i ekstensywną) jako wyższy stopień pobudzenia pewnej władzy umysłowej, w tym przypadku władzy wyobraźni. Tym samym podwyższona aktywność wyobraźni spowodowana odczuciem smutku, wstrętu itp. reprezentuje żywotność sił umysłu. Zdolność do odczuwania namiętności wskazuje zatem na aktywne siły naszego umysłu. Mendelssohn potwierdza to w liście z 15 maja 1756 roku do Friedricha Gabriela Rosewitza, w którym pisze, że uczucie bólu wskazuje na pewien stopień realności. Nie chodzi przy tym o to, że odczucia mają jakąkolwiek treść poznawczą, bo za ich pomocą nie poznajemy świata. Odczucia są autoreferencyjne, to znaczy, że odsyłają do samych siebie. Poprzez odczuwanie namiętności poznajemy jedynie, że jesteśmy zdolni do odczuwania namiętności.

Konsekwencją przyjęcia teorii odczuć mieszanych było z kolei to, że Mendelssohn musiał oddzielić przedmiotową treść reprezentacji od subiektywnej treści przedstawień umysłowych. Innymi słowy, istnieje możliwość, że przedmiotowo tragicznej treści, jak trzęsienie ziemi w Lizbonie czy krwawa bitwa, może odpowiadać w umyśle przedstawienie rodzące przyjemność. Chcę przy tym podkreślić, że Mendelssohn nie mówi tu wyłącznie o artystycznym przedstawieniu trzęsienia ziemi lub bitwy, ale o przedstawieniu jako takim, w tym o przedstawieniu umysłowym.

W tekście Rhapsodie, oder Zusätze zu den Briefen über die Empfindungen, będącym uzupełnieniem jego młodzieńczych Listów o odczuciach Mendelssohn tłumaczy, że każde przedstawienie może być rozpatrywane $\mathrm{z}$ dwóch 
stron. Z jednej strony, przedstawienia posiadają swoją stronę przedmiotową, gdzie przedstawienie jest wywoływane przyczynowo przez przedmiot reprezentacji. Z drugiej strony, przedstawienie posiada swoją stronę subiektywną, odnoszącą się do myślącego podmiotu, będącą przyczynowo niezależną od przedmiotu przedstawienia. $\mathrm{W}$ tym sensie przedstawienie rozpatrywane od strony subiektywnej może posiadać elementy rodzące przyjemność, nawet jeżeli przedmiotowa strona przedstawienia zawiera elementy powodujące smutek. Odczucia mieszane dają się zatem wyjaśnić poprzez rozróżnienie dwóch stron - subiektywnej i obiektywnej - przedstawień.

O ile przedmiotową treść przedstawienia wyznaczało określone wydarzenie w świecie, o tyle subiektywną treść przedstawienia stanowiła sama świadomość spełnienia określonego aktu poznawczego lub aktu pożądania, to jest świadomość skutecznej realizacji określonej władzy umysłu. Poznaniu rzeczy przedmiotowo nieprzyjemnych towarzyszy zatem świadomość odczuwania nieprzyjemności. Z kolei poznaniu rzeczy przedmiotowo przyjemnych towarzyszy świadomość odczuwania przyjemności. Analogicznie jest w przypadku poznania oraz pożądania dobra i zła. Poznaniu rzeczy przedmiotowo dobrej i złej towarzyszy zgoda na dobro i niezgoda na zło. Pamiętajmy przy tym, że aby uniknąć błędnego koła, Mendelssohn nie mówi tu o relacji wynikania pomiędzy poznaniem dobra i zła a odczuciem ich aprobaty lub dezaprobaty. Subiektywna oraz obiektywna strona aktu poznawczego to jedynie dwie strony tego samego. Równocześnie towarzyszące poznaniu rzeczy nieprzyjemnych odczucie nieprzyjemności stanowi ekspresję aktywności sił umysłu. Pobudzenie sił umysłu reprezentuje z kolei obiektywnie wyższy stopień doskonałości niż brak takiego pobudzenia, stąd wzrost aktywności sił umysłu może rodzić odczucie przyjemności. Odczucie nieprzyjemności w poznaniu rzeczy nieprzyjemnych oraz przyjemność płynąca $z$ aktywności władz umysłowych stanowią jednak dwa odrębne poziomy poznawcze, dlatego nie są one w stanie wpływać na siebie. Możemy mieć zatem negatywne odczucia w stosunku do obiektu przedstawienia oraz pozytywne odczucia w stosunku do samego przedstawienia.

Do tej pory mowa była o przedstawieniach umysłowych. Jaka jest jednak rola przedstawienia artystycznego w wywoływaniu odczuć mieszanych? Pamiętajmy, że sztuka lub poznanie piękna, które przez współczesnych często były traktowane łącznie, nie stanowiły dla autora Listów o odczuciach uprzywilejowanej formy dostępu do jakiejś rzeczywistości pozaludzkiej. Dla Mendelssohna sztuka może jednak sprawić, że staniemy się świadomi różnicy pomiędzy obiektem przedstawienia a samym przedstawieniem. Dzięki temu 
jesteśmy $\mathrm{w}$ stanie odczuwać przyjemność z obcowania z przedstawieniem rzeczy, które przedmiotowo przyjemne nie są. Rolą sztuki jest zatem przede wszystkim uświadomienie dystansu pomiędzy przedstawieniem a obiektem przedstawienia. W tym sensie Mendelssohn mówi również o mimetycznej roli sztuki. Błędem byłoby twierdzenie, że funkcją przedstawienia artystycznego miałoby być jedynie wierne przedstawienie otaczającego świata. Imitacja nie polega tu na ślepym naśladowaniu natury, ale na takim, które uczyni widoczną różnicę pomiędzy naśladowaniem a naśladowanym obiektem. Imitacja nie ma zatem na celu zatarcia różnicy pomiędzy reprezentacją a przedmiotem reprezentacji, ale uwypuklenie wspomnianej różnicy, a to czyni ją bliższą pojęciu oszustwa (apate) niż naśladownictwa. Przedstawienie artystyczne stanowi narzędzie, za pomocą którego jesteśmy w stanie odnieść się nie do reprezentowanego obiektu, ale do samego aktu reprezentacji obecnego przykładowo w iluzji artystycznej. Dzięki temu sztuka może również wzbudzać namiętności, które stanowią kryterium oceny przedstawienia.

Instrumentalny charakter sztuki i jej funkcji imitacyjnej wyraźnie odróżnia ujęcie Mendelssohna od tradycyjnego pojmowania roli sztuki i imitacji, obecnego chociażby u Hutchesona i Wolffa. Ci ostatni twierdzili, że imitacja jest celem ostatecznym sztuki. Mendelssohn z kolei naśladownictwu przypisuje rolę instrumentalną polegającą na wywoływaniu odczucia przyjemności płynącej z obcowania z medium sztuki. Dlatego też mówi on $\mathrm{w}$ Ueber die Hauptgrundsätze der schönen Kunste und Wissenschaften (1757), że sztuka ma za zadanie wzbudzać namiętności. Tylko pozornie zostaje tu jednak powtórzone rozwiązanie zawarte chociażby w Réflexions critiques sur la poésie et sur la peinture Du Bos'a. Mednelssohn stara się bowiem znaleźć prawa umysłu rządzące namiętnościami.

Zrozumienie funkcji imitacji przedstawienia artystycznego, którą to funkcję można z powodzeniem rozciągnąć na wszelkie przedstawienia umysłowe, pozwala również wyjaśnić, w jakim kontekście pojawia się u Mendelssohna pojęcie „życia”, stanowiące bezpośrednie odwołanie do Baumgartenowskiego pojęcia „życia poznania estetycznego”. Mendelssohn zauważa, że imitacyjny element przedstawienia jest konieczny, aby wywołać w nas reakcję emocjonalną. Innymi słowy, przedstawienie umysłowe musi zachować związek przyczynowy, choć niekoniecznie związek bezpośredni, z reprezentowanym obiektem, aby móc mówić o emocjonalnej odpowiedzi na poznanie lub pożądanie takiego obiektu. Odczucia rozpatrywane są bowiem jako mechaniczna reakcja na własności reprezentowanego obiektu. Strach przed burzą powodowany jest tym, że burza zagraża życiu, a przyjemność z jedzenia czekolady 
wywołana jest własnościami czekolady itp. Jednakże dzięki odróżnieniu aktu przedstawienia od obiektu przedstawienia możemy mówić o odczuciu zadowolenia lub niezadowolenia, które powodowane jest samą żywotnością lub brakiem żywotności władz poznawczych (resp. władz wyobraźni). Możemy zatem odczuwać przyjemność powodowaną aktywnością władz umysłu bez względu na to, czy dany obiekt powoduje przyjemne, czy nieprzyjemne odczucia.

Podsumowując: Mendelssohn rozwija rozróżnienie na subiektywną oraz obiektywną doskonałość poznania, które zaczerpnął od Baumgartena, a także wykorzystuje je, rozwijając autorską koncepcję odczuć mieszanych. Przenosi również główny punkt zainteresowań z przedstawienia doskonałości przedmiotu na przedstawienie własnych stanów umysłowych. Mendelssohn rozwija także zagadnienie mimesis, utrzymując, że imitacja stanowi środek dla uwypuklenia różnicy pomiędzy porządkiem przedmiotowym a przedstawieniowym, przypisując przyjemność płynącą z odbioru sztuki temu ostatniemu.

\section{Etyka i estetyka}

W perspektywie rozważań dotyczących odczuć zmieszanych jaśniejsze wydaje się odrzucenie przez Mendelssohna poglądów empirystów dotyczących dobrego życia, opierających się na doświadczeniach przyjemności. Mendelssohn nigdzie wprawdzie nie wymienia $z$ imienia i nazwiska osób, z którymi polemizuje, ale w Listach o odczuciach wspomina o dziele Essai de philosophie morale, którego autorem był Pierre Louis Maupertuis, rektor akademii nauk w Berlinie. Ten ostatni twierdził, że można przeprowadzić rachunek przyjemności i nieprzyjemności i na tej podstawie określić, czy dane życie jest dobre lub złe. W przypadku, w którym bilans rachunku przyjemności i nieprzyjemności jest negatywny, możemy mówić, że dane życie niewarte jest przeżycia. Tym samym przykładowo jeżeli rachunek przyjemności jest negatywny, dopuszczamy możliwość samobójstwa.

Mendelssohn nie traktował wprawdzie teorii rachunku przyjemności poważnie. Wskazywał jej błędy. Po pierwsze, odwołując się do teorii odczuć mieszanych, twierdził, że nie możemy wyodrębnić jasnych przypadków odczucia przyjemności i nieprzyjemnościi w adekwatny sposób powiązać ich z przedmiotem danej przyjemności. Przedmiotowo nieprzyjemny stan rze- 
czy może rodzić odczucie przyjemności i na odwrót. Po drugie, błędnie zakłada się tu, że każda nieprzyjemność pomniejsza ilość szczęścia. Możemy wyobrazić sobie przypadki, w których ludzie nie tylko chcą cierpieć, ale również czerpią przyjemność z odczuć negatywnych, jak w przypadku uczucia melancholii. Autor Listów o odczuciach odrzuca również przekonanie, które utożsamia cel dobrego życia z odczuwaniem przyjemności. Przyznaje on wprawdzie, że empiryzm ma rację w tym sensie, że każde dobre działanie jest połączone $\mathrm{z}$ odczuciem przyjemności będącej zgodą na dobro oraz że sama przyjemność jest $\mathrm{w}$ moralnym działaniu istotnym elementem, będąc dla takiego działania pobudką. Problem polega jednak na tym, że traktuje się tu przyjemność jako jakość prostą i pierwotną. Innymi słowy, empiryzm nie dość dokładnie analizuje samo pojęcie przyjemności. Przyjemność nie może też być pojęciem bazowym, ponieważ musi istnieć racja, dla której wynosimy jedną przyjemność nad drugą. Nie twierdzimy przecież, że pożądamy dobra, ponieważ uważamy, że jest ono przyjemne, ale pożądamy przyjemności, ponieważ twierdzimy, że jest dobra. Racją, którą decyduje o tym, co jest przyjemne, a co nie jest przyjemne, jest zaś doskonałość, ewentualnie doskonalenie, to znaczy przejście od niższego do wyższego stopnia doskonałości. Oznacza to zaś, że jeżeli doskonałość (doskonalenie) jest podstawą przyjemności, to doskonałość (doskonalenie), a nie przyjemność jest najwyższym dobrem wyznaczającym wartość życia etycznego. Z drugiej strony, przyjemność odgrywa istotną rolę w teorii dobra najwyższego, odkąd, zgodnie z założeniami filozofii umysłu Wolffa, doświadczanie doskonałości stanowi przyczynę doświadczenia przyjemności. O ile zatem przyjemność nie stanowi obiektywnej racji do działania, o tyle wciąż może ona pełnić funkcję motywacji do nabywania cnoty i samodoskonalenia.

Związek estetyki i moralności omawiany jest również w nieukończonym przez Mendelssohna tekście Verwandschaft des Schönen und Guten (1757-1760). Mendelssohn polemizuje w nim z przekonaniem Rousseau, który „obwiniał nauki i sztuki piękne [...] o psucie moralności”"16. Autor Listów o odczuciach twierdzi, że istnieje pokrewieństwo pomiędzy doświadczeniem przyjemności płynącym z obcowania z pięknem a doświadczeniem dobra. Jednakże, aby zrozumieć charakter tego pokrewieństwa, należy najpierw rozważyć podział w obrębie władz poznawczych wprowadzony przez Mendelssohna za Wolffem i Baumgartenem.

${ }_{16}$ Tenże, Verwandschaft des Schönen und Guten, [w:] JubA 2, 181. 
O ile rozum (Vernunft) w poznaniu jasnym i wyraźnym pozwala nam rozróżnić to, co prawdziwe i nieprawdziwe, dobre i złe, piękne i brzydkie, o tyle posiadamy również zmysłowość, która to, co prawdziwe i fałszywe (poprzez tzw. Bonsens) $)^{17}$, dobre i złe (poprzez odczucia), piękne i brzydkie (poprzez smak), uobecnia nam w przedstawieniu mętnym poprzez odczucia ${ }^{18}$. Co istotne, władze rozumu i zmysłowości nawzajem się uzupełniają. Zmysłowość ma pouczać rozum, a rozum kierować zmysłowością. Pamiętajmy przy tym, że Mendelssohn nie odwołuje się tu do irracjonalnych elementów $\mathrm{w}$ naszym poznaniu. Wręcz przeciwnie. Rozum i zmysły działają wedle podobnych reguł, z tym że rozum jest władzą dyskursywną, potencjalnie zdolną do uchwycenia wszystkich instancji pośrednich w ciągu sylogizmu, a zmysły są władzą działającą szybko w taki sposób, że ujmuje się jedynie pierwszy i ostatni człon rozumowania. Dlatego też Mendelssohn może nazwać zmysłowość „wyćwiczonym rozumem” (geübte Vernunft).

Popełniamy tym samym błąd, gdy chcemy zredukować nasze sądy o dobru, prawdzie i pięknu do wnioskowania rozumu. Rozróżniamy dobro i zło, prawdę i fałsz, piękno i brzydotę, opierając się w tych rozróżnieniach często jedynie na władzy zmysłowości. Co więcej, nie możemy posiadać rozumowych pojęć wyraźnych, jeżeli nie wyćwiczymy zdolności do rozpoznawania i rozróżniania rzeczy w zmysłowym poznaniu mętnym. Innymi słowy, nie powiemy o człowieku, że posiada pojęcie „stołu”, jeżeli w doświadczeniu przypisuje pojęcie „stołu” krzesłom, a nie stołom. Zmysłowość jest zatem nie tyle pochodną posiadania pojęć rozumu, ile warunkiem koniecznym ich posiadania.

Z drugiej strony, zmysłowość jest również władzą ujmowania wielości przedstawień w jedno, to jest w zjawisko (Erscheinung, phaenomena), które przynależy zarówno obiektywnemu, jak i subiektywnemu aspektowi poznania. Istotne jest, że owa wielość nie daje się sprowadzić do sumy elementów, ale ma odrębną jakość, którą zawdzięcza jednoczącej funkcji niższej części władz umysłu, czyli zmysłowości. Rozum, czyli wyższa władza poznania, może z kolei wyodrębnić w owej całości poznania składowe oraz złożyć owe elementy w całość. O ile jednak zmysłowość dokonuje aktu jednoczenia mo-

${ }^{17}$ W recenzji Baumgartenowskiej Estetyki, Aestheticorum Pars altera (1758), Mendelssohn utożsamia pojęcie Bonsens z pojęciem analogon rationis. Por. tenże, A. G. Baumgarten: Aestheticorum Pars altera, [w:] JubA 4, s. 264.

${ }^{18}$ Por. tenże, Verwandschaft des Schönen und Guten, [w:] JubA 2, s. 182. 
mentalnie, o tyle w przypadku rozumu akt jednoczenia elementów odbywa się nie bez trudu i w dłuższym czasie.

Powyższe rozróżnienia znajdują istotne zastosowanie w rozważaniach na temat rozumowań praktycznych. Dobro i zło będące racją działań nie muszą być reprezentowane poprzez rozum. Dobro i zło może być poznane poprzez idee mętne przynależne zmysłowości, a pomimo to mogą bardziej oddziaływać na naszą wolę. Dzieje się tak, ponieważ przedstawienia mętne są bogatsze w treść niż przedstawienia wyraźne oraz oddziałują szybciej. Idee mętne oddziałują bowiem na wolę przyczynowo, a nie logicznie, jak w przypadku idei rozumu. Stanowią mechaniczną motywację do działania, a nie logiczną rację dla tych działań. Co więcej, jak twierdzi Mendelssohn, logiczna racja nie może pobudzać do działania, jeżeli nie zawiera elementu motywującego wolę, to jest, jeżeli nie rodzi odczucia przyjemności lub nieprzyjemności będącego pobudką działania.

Jak pisze Mendelssohn w Von der Herrschaft über die Neigungen, cnota nie opiera się zatem jedynie na znajomości nakazów postępowania. Rozum może wprawdzie pouczać cnotę, ale ta ostatnia opiera się przede wszystkim na biegłości i gotowości do moralnego działania, których nabywamy poprzez ćwiczenia cnoty. Ćwiczenia cnoty opierają się z kolei na ćwiczeniach niższej władzy zmysłowej do rozpoznawania rzeczy dobrych i złych. Zmysłowość, a ściślej jej władza do łączenia oraz rozdzielania przedstawień, umożliwia rozpoznawanie rzeczy wartościowych i stosowne do tych wartości działanie dzięki pobudzaniu woli. $Z$ drugiej strony, ćwiczenia wyobraźni - tak poprzez kontakt z pięknem, jak i z harmonią matematyczną itp. - pobudzają żywotność wyobraźni, tj. sprawiają, że władza wyobraźni doskonali się w łączeniu i rozdzielaniu przedstawień zmysłowych. Tym samym doskonali się również nasza zdolność do rozpoznawania dobra, zła i stosownego działania. Cnota nie jest zatem wyłącznie poznaniem moralnych reguł i obowiązków, ale przede wszystkim zmysłową zdolnością do rozpoznawania tych reguł w zjawisku (interpretowanym tak $\mathrm{w}$ sensie przedmiotowym, jako reprezentacja czegoś, jak i podmiotowym, jako posiadanie przedstawień umysłowych).

$\mathrm{Na}$ tym tle jaśniejsze wydaje się również zainteresowanie Mendelssohna teorią prawdopodobieństwa, którą opracowywał w tekstach O prawdopodobieństwie i O pewności na podstawie pism Wolffa, Baumgartena i (prawdopodobnie) Jacoba Bernoulliego. Mendelssohn przejmuje od Wolffa definicję prawdopodobieństwa (którą Wolff zaczerpnął od Bernoulliego) Teoria ta mówi, że z wiedzą prawdopodobną mamy do czynienia wtedy i tylko wtedy, gdy wniosek nie jest w pełni zdeterminowany przez przesłanki, to jest, gdy 
wyciągamy konkluzje na podstawie niepełnych informacji ${ }^{19}$. Mendelssohna nie interesuje przy tym formalno-matematyczna strona teorii prawdopodobieństwa, ale to, jakie konsekwencje niesie ona dla rozważań dotyczących rozumowania praktycznego. Jego intencją nie jest zatem rozwijanie formalnej strony teorii prawdopodobieństwa, ale zbadanie konsekwencji, jakie ta teoria niesie dla rozważań natury filozoficznej, szczególnie z zakresu etyki.

Mendelssohn twierdzi, że o ile w przypadku twierdzeń rozumu możemy mieć do czynienia z pewnością obiektywną, to $\mathrm{w}$ przypadku rozumowania praktycznego musimy najczęściej polegać na pewności subiektywnej. Najczęściej nie mamy bowiem do czynienia z poznaniem jasnym i wyraźnym, ale $\mathrm{z}$ poznaniem mętnym, którego elementów nie jesteśmy często $\mathrm{w}$ stanie wyodrębnić. Możemy być zatem obiektywnie pewni zasad etyki w tym sensie, że jesteśmy w stanie, a przynajmniej Mendelssohnowi wydaje się, że jesteśmy w stanie, przeprowadzić kompletny dowód twierdzeń etycznych, ale zastosowania tych twierdzeń w życiu możemy być pewni jedynie subiektywnie. Działamy bowiem na podstawie niepełnego zbioru przesłanek. W sytuacjach praktycznych rozum nie wystarcza i musimy oprzeć się na władzy zmysłów. Ta ostatnia kieruje zaś naszymi działaniami poprzez motywacyjny aspekt odczuć oraz dobrych nawyków, które nabywamy poprzez ćwiczenia. Odczucia oraz nawyki dostarczają nam subiektywnej pewności, stanowiącej warunek wystarczający, aby działać.

W tym kontekście funkcją ćwiczeń (treningu) naszych władz poznawczych, jest takie rozwijanie naturalnych zdolności (Fähigkeiten), które prowadzi do wykształcenia biegłości (Fertigkeit) w rozpoznawaniu odpowiednich racji do moralnego działania oraz do podjęcia samego zgodnego $\mathrm{z}$ tymi racjami działania. Na tym też polega kształtowanie moralnej zmysłowości (sittliche Empfindlichkeit), którą Mendelssohn określa również mianem „drugiej natury”. Ta ostatnia opiera się na osiągniętej w drodze treningu zdolności do rozpoznawania moralnych aspektów rzeczywistości oraz nabyciu dyspozycji do moralnego działania. Wykształcona moralność przejawia się więc w takimi działaniu, które będzie niejako nawykową reakcją na sytuację moralną. Przykładowo: wykształcona moralność będzie przejawiać się w tym, że nawykowo pomożemy pewnej staruszce przejść przez ulice, gdy widzimy, że taka potrzeba zachodzi, a nie w tym, że pomożemy staruszce po rozważeniu wszystkich za i przeciw. Podobnie w matematyce. Mendelssohn nie przed-

${ }^{19}$ C. Wolff, Philosophia rationalis, sive logica, [w:] tenże, Gesammelte Werke II:5, I. Ecole (Hrsg.) Georg Olms, Hildesheim 1983, § 578. 
stawia wprawdzie poniższego porównania, ale wydaje się uzasadnione, by twierdzić, że tak jak wykształcona moralność opiera się na umiejętności nawykowego działania w świecie, tak w przypadku matematyki o umiejętności dodawania świadczy nie tylko znajomość techniki dodawania, ale i biegłość w stosowaniu tej techniki przejawiającej się w działaniu nawykowym. Potrafi liczyć ten, kto dodaje dwa jabłka do dwóch jabłek i na tej podstawie otrzymuje wynik cztery jabłka. Biegłość w dodawaniu przejawia się jednak dopiero wówczas, gdy nawykowo dostrzegamy (i w tym sensie posiadamy racje prawdopodobne), że wynik działania $2+2$ równa się 4 .

\section{Teoria trzech władz}

Oceniając wkład Mendelssohna do historii filozofii oraz omawiając jego rozumienie pojęcia estetyki, należy podnieść znaczenie teorii trzech władz: władzy poznania, pożądania oraz smaku. Zwykło się twierdzić, że Mendelssohn odszedł w tym miejscu od teorii umysłu Wolffa, redukującej pozostałe aspekty umysłu do władzy poznania, oraz przybliżył się do Kantowskiego rozróżnienia na rozum teoretyczny, praktyczny oraz władzę sądzenia. Przy formułowaniu tego typu sądów należy jednak zachować ostrożność. Po pierwsze, Mendelssohn nigdy nie porzucił myśli o konieczności unifikacji władz umysłu. Szczególnie mocno wyraża się to w prezentowanym przeze mnie Mendelssohnowskim ujęciu sądu estetycznego, który łączy w sobie władzę poznawczą, władzę pożądania oraz sąd smaku. Sąd estetyczny ma naturę poznawczą, odkąd jest on poznaniem doskonałości. Uwzględnia on również władzę pożądania, odkąd pożądamy doświadczenia przyjemności. Po drugie, poznawcza natura sądu estetycznego wyraźnie odróżnia teorię Mendelssohna od niekognitywnego ujęcia sądu estetycznego u Kanta.

Może pojawić się pytanie: czy Mendelssohn, wprowadzając doktrynę trzech władz, nie zerwał z racjonalizmem, którego tak gorąco bronił w swoich pismach? Wątpliwość dotyczy tu przede wszystkim tego, czy wprowadzając dodatkową władzę do tradycyjnych dwóch (władzy pożądania i poznania), nie włączał on do aktu sądzenia elementów irracjonalnych? Uważna lektura dzieła Morgenstunden oder Vorlesungen über das Daseyn Gottes ${ }^{20}$, w którym

${ }^{20}$ Por. M. Mendelssohn, Morgenstunden oder Vorlesungen über das Daseyn Gottes, [w:] JubA 3.2 . 
to doktryna trzech władz doczekała się najpełniejszego opracowania, pozwala jednak na to pytanie odpowiedzieć negatywnie. Po pierwsze, Mendelssohn nigdzie w tekście nie postuluje całkowitej separacji trzech władz. Twierdzi wprawdzie, że pomiędzy władzą poznania oraz pożądania należy uwzględnić władzę odczuwania, ale wszystkie te władze łączą się w ramach jednego aktu sądzenia. Po drugie, o ile można zgodzić się z tezą, że władza odczuwania była władzą niedyskursywną, o tyle nie można powiedzieć, że stanowiła ona irracjonalny element funkcjonowania umysłu. Wynika to z faktu, że choć odczucia nie muszą być przyczynowo związane z rozumowymi ideami wyraźnymi, to mogą one jednak podlegać kontroli rozumu, co znaczy, że pomiędzy rozumem a odczuciami może istnieć związek logiczny. Innymi słowy, idee rozumu mogą być racją za odrzuceniem lub zaakceptowaniem określonych odczuć.

Czym jednak była sama władza odczuwania? W Morgenstunden nazywana również władzą aprobaty (Billigungsvermögen) była odpowiedzialna za nadbudowany nad aktem poznawczym lub nad aktem sądu praktycznego akt zgody na odpowiednią realizację tego aktu. Innymi słowy, władza aprobaty reprezentowała poprawną realizację danego aktu. Mendelssohn, co widzieliśmy analizując zagadnienie odczuć mieszanych, zauważa bowiem, że w ramach funkcjonowania umysłu możemy uwzględnić przedstawienia, które ani nie mają na celu wzbudzania pożądania, ani nie mają treści poznawczej. Co więcej, istnieją uczucia, które nie mają natury pożądania kogoś lub czegoś. Przykładowo obcowanie z dziełem sztuki może rodzić przyjemne odczucia, ale nie oznacza to w żadnym wypadku, że pożądamy odpowiedniego dzieła sztuki. Odczucia (Empfindungen) mogą (choć nie muszą) wzbudzać pożądania, ale istnieją również tzw. Empfindnisse, które nie wzbudzają pożądania, a pomimo to rodzą odczucie przyjemności i nieprzyjemności, które odczuwamy w aktach bezinteresownej kontemplacji.

Władza odczuwania odgrywa również rolę pośredniczącą pomiędzy władzą poznania a władzą pożądania. Wynika to z faktu, że o ile funkcją władzy poznania jest dostosowanie przedstawienia umysłowego do przedstawianego obiektu, o tyle w przypadku władzy pożądania jest odwrotnie - skierowana jest ona ku dostosowaniu obiektu przedstawienia do przedstawienia umysłowego. Elementem, który umożliwia komunikację pomiędzy obiema władzami i integrację obu władz jest zaś władza odczuwania. W tym sensie Mendelssohn może mówić zatem, że celem władzy odczuwania jest dobro, co znaczy, że władza odczuwania pośrednio umożliwia nam dostosowywanie świata do naszego pojęcia dobra, piękna i porządku. 
Z jednej strony Mendelssohn podkreśla zatem, że władza odczuwania nie pokrywa się z władzą pożądania w tym sensie, że możemy rozważać przykładowo piękno sztuki czy przyrody w całkowitym oderwaniu od faktu pożądania kontemplowanych obiektów. Ostatecznie możemy podziwiać określone przedstawienie w sztuce, ale zarazem nie chcieć, aby znalazło ono swoją realizację w rzeczywistości. Mogę czerpać satysfakcję z oglądania horrorów, ale nie musi to oznaczać, że chcę przeżywać horror. Władza odczuwania nie pokrywa się również z władzą poznania, odkąd przedmiotem osądzanym przez władzę odczuwania nie jest (jedynie ${ }^{21}$ ) przedmiot zewnętrzny, czyli treść aktu poznawczego, ale przede wszystkim umysłowe przedstawienie tego przedmiotu. Z drugiej strony, odczucie przyjemności lub nieprzyjemności jest powiązane z aktami poznawczymi w ten sposób, że realizacja (forma) pewnych aktów poznawczych (ale nie treść tych aktów) może powodować odpowiednie odczucie przyjemności lub nieprzyjemności wynikające ze stopnia doskonałości lub niedoskonałości, ewentualnie z przejścia na niższy lub wyższy stopień doskonałości. $\mathrm{W}$ tym sensie każdy akt poznawczy zawiera pewnego rodzaju przyzwolenie lub zgodę na ten akt, ponieważ określone akty poznawcze mogą rodzić mniejszą lub większą przyjemność rozumianą jako niedyskursywna reprezentacja stopnia doskonałości formy poznania. Co więcej, odkąd pożądamy rzeczy, które są przyjemne, pożądamy również takiej formy poznania oraz takich rzeczy, które będą sprawiać największą przyjemność, czyli rozkosz (Lust, Vergnügen). Władza pożądania może zatem pożądać takiej realizacji aktu poznawczego, który sprawi nam największą przyjemność, co znaczy, że może stanowić motywację do takiego działania w świecie, które zapewni nam wzrost przyjemności. W tym też sensie możemy mówić, że władza poznania i władza pożądania nie stanowią odrębnych władz, ale są dwiema stronami jednej władzy umysłu, pojętego za Wolffem i Leibnizem jako vis representativa. Różnica pomiędzy nimi polega jedynie na tym, że o ile władzę poznania charakteryzuje kierunek przedmiot-przedstawienie umysłowe, o tyle władzę pożądania cechuje kierunek przedstawienie umysłowe-przedmiot. Władza pożądania ma za zadanie urzeczywistniać mającą jedynie pewną istotę (ale nie istnienie) treść przedstawienia umysłowego, przy czym owe urzeczywistnienie może dotyczyć zarówno przedmiotów

\footnotetext{
${ }^{21}$ Mendelssohn zachowuje przekonanie Wolffa i Baumgartena o metafizycznym związku pomiędzy cechami przedstawień umysłowych a cechami przedstawionego obiektu. Stąd odczucie przyjemności może, choć nie musi, być powodowane przyczynowo przez własności reprezentowanego obiektu.
} 
w świecie zewnętrznym, jaki w obrębie samego umysłu, tj. władza pożądania może dążyć do doskonalszego ukształtowania władz poznawczych i doskonalenia formy poznania. Jeżeli zatem mówiliśmy o wpływie władzy poznania na władzę pożądania, to ta relacja zachodzi również w drugą stronę. Władza pożądania może wpływać na kształtowanie formy aktów poznawczych, tj. może kształtować sztukę myślenia. Elementem integrującym obie władze jest zaś władza odczuwania. Ostatecznym celem odczucia przyjemności lub nieprzyjemności (i estetyki jako takiej) byłaby zatem integracja władz umysłu. Od tego miejsca już tylko krok od rozważań Kanta zawartych na kartach Krytyki władzy sądzenia.

\section{Bibliografia}

Beiser F., Diotima's Children: German Aesthetic Rationalism from Leibniz to Lessing, Oxford University Press, New York 2009.

Hammermeister K., The German Aesthetic Tradition, Cambridge University Press, Cambridge 2002.

Hutcheson F., An Inquiry into the Original of Our ideas of Beauty and Virtue (1725), (ed.) K. Haakonssen, Liberty Fund, Indianapolis 2002.

Kozak P., Wychować Boga. Estetyka antropologiczna Alexandra Gottlieba Baumgartena na tle myśli niemieckiej pierwszej połowy XVIII wieku, Wyd. UW, Warszawa 2013.

Mendelssohn M., Gesammelte Schriften Jubiläumsausgabe, hrsg. A. Altmann, F. Bamberger, H. Borodianski, I. Elbogen, J. Guttmann, E. Mittwoch, S. Rawidowicz, B. Strauss, L. Strauss, Friedrich Frommann, Berlin, Stuttgart 1929-1976.

Pollok A., Einleitung, [w:] M. Mendelssohn, Ästhetische Schriften, hrsg. A. Pollok, Felix Meinder Verlag, Hamburg 2006.

Spinoza B., Etyka w porzadku geometrycznym dowiedziona, przeł. I. Halpern-Myslicki, [w:] tenże, Traktaty, Wyd. Antyk, Kęty 2003.

Wolff C., Philosophia rationalis, sive logica, [w:] tenże, Gesammelte Werke II:5, I. Ecole, hrsg. Georg Olms, Hildesheim 1983. 


\begin{abstract}
Moses Mendelssohn's Aesthetics as Philosophy of Psychology

The aim of the text is an elaboration of the Moses Mendelssohn's aesthetics and its connections to the German philosophical thought of Enlightenment. I analyze the issue of sensations and so-called mixed sensations and I argue that they are the necessary condition of cognition. I present the relations between aesthetics and ethics and I elaborate so-called theory of three faculties. I argue that sense is an element conjoining action and cognition.
\end{abstract}

Key words: Mendelssohn, aesthetics, ethics, sensibility, feelings 